\title{
The Age of Milton Friedman
}

\section{Citation}

Shleifer, Andrei. 2009. "The Age of Milton Friedman." Journal of Economic Literature 47 (1): 12335. https://doi.org/10.1257/jel.47.1.123.

\section{Permanent link}

http://nrs.harvard.edu/urn-3:HUL.InstRepos:41555812

\section{Terms of Use}

This article was downloaded from Harvard University's DASH repository, and is made available under the terms and conditions applicable to Other Posted Material, as set forth at http:// nrs.harvard.edu/urn-3:HUL.InstRepos:dash.current.terms-of-use\#LAA

\section{Share Your Story}

The Harvard community has made this article openly available.

Please share how this access benefits you. Submit a story.

Accessibility 


\title{
The Age of Milton Friedman
}

\author{
ANDREI SHLEIFER*
}

\begin{abstract}
Between 1980 and 2005, as the world embraced free market policies, living standards rose sharply, while life expectancy, educational attainment, and democracy improved and absolute poverty declined. Is this a coincidence? A collection of essays edited by Balcerowicz and Fischer argues that indeed reliance on free market forces is key to economic growth. A book by Stiglitz and others disagrees. I review and compare the two arguments.
\end{abstract}

\section{Introduction}

$\mathrm{T}$ he last quarter century has witnessed remarkable progress of mankind. The world's per capita inflation-adjusted income rose from $\$ 5,400$ in 1980 to $\$ 8,500$ in 2005. Schooling and life expectancy grew rapidly, while infant mortality and poverty fell just as fast. Compared to 1980, many more countries in the world are democratic today.

The last quarter century also saw wide acceptance of free market policies in both rich and poor countries: from private ownership, to free trade, to responsible budgets, to lower taxes. Three important events mark the beginning of this period. In 1979, Deng Xiao Ping started market reforms in China, which over the quarter century lifted hundreds of millions of people out of poverty. In the same year, Margaret Thatcher was elected Prime Minister in Britain, and initiated her radical reforms and a long period of growth. A year later, Ronald Reagan was elected President of the United States and

\footnotetext{
* Shleifer: Harvard University.
}

also embraced free market policies. All three of these leaders professed inspiration from the work of Milton Friedman. It is natural, then, to refer to the last quarter century as the Age of Milton Friedman.

The association between free market policies and social progress notwithstanding, economists remain divided in their assessments of this Age. Two recent books illustrate the divisions. A collection of papers edited by Leszek Balcerowicz and Stanley Fischer-Living Standards and the Wealth of Nations: Successes and Failures in Real Convergence (MIT Press, 2006)_endorses free market policies. A volume by Joseph E. Stiglitz, José Antonio Ocampo, Shari Spiegel, Richardo FfrenchDavis, and Deepak Nayyar-Stability with Growth: Macroeconomics, Liberalization, and Development (Oxford University Press, 2006) - rejects them. A joint review of these two books allows for a brief look at both the facts and the disagreements.

I begin this review by quickly summarizing the salient facts about the world economy and society over the last quarter century. I then consider the two books in turn. 


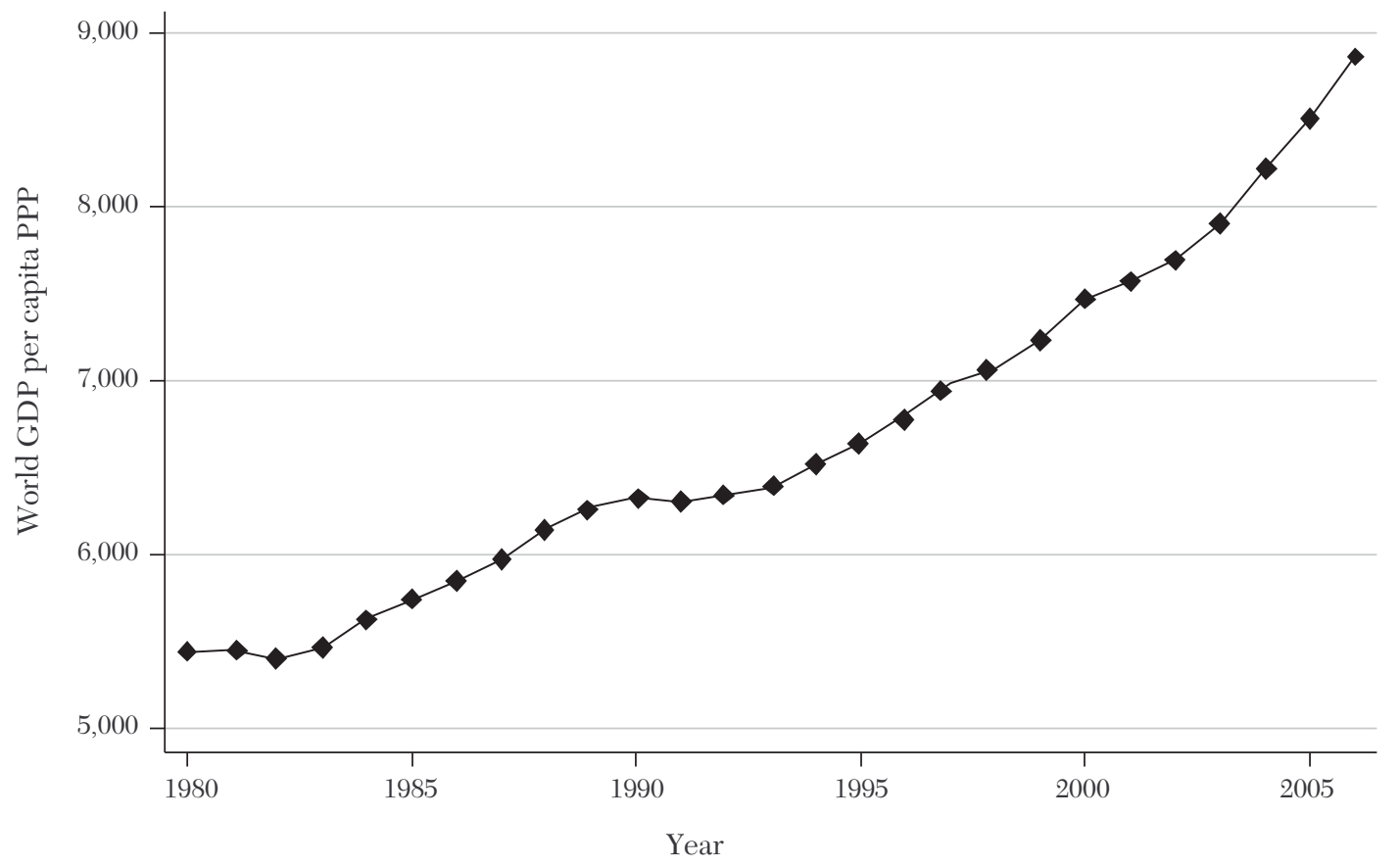

Figure 1. World GDP Per Capita PPP

(Constant 2000 International Dollar)

Source: World Bank 2006b.

\section{Basic Facts}

Some of the central facts of economic and social development during 1980-2005 can be easily summarized in pictures. Figure 1 shows the evolution of world per capita GDP at purchasing power parity between 1980 and 2005. During this period, world per capita income grew at about 2 percent per year.

The rest of the figures are organized by region. Figure 2 presents the growth of per capita income for the main developing regions of the world. Figure 2 shows rapid growth in East and South Asia (the economic history of the last twenty-five years is indeed the story of Asia), slow growth in Latin America, and stagnation in Africa. Figure 2 also suggests that the so-called transition economies of the former Soviet Union and Eastern Europe grew slowly during the 1980s, declined sharply after the beginning of economic reforms, but then expanded rapidly over the last decade.

Figure 3 shows a remarkable decline in infant mortality in all regions, with the worldwide population-weighted average dropping from 64.5 to 37.5 per thousand births.

Figure 4 presents data on life expectancy, revealing strong increases in all regions but transition economies and Africa.

Figure 5 shows the gains in education around the world. Worldwide populationweighted years of schooling grew from 4.4 in 1980 to almost 6 in 1999.

Figure 6 presents the now-familiar picture of growth in democracy. With the conspicuous 


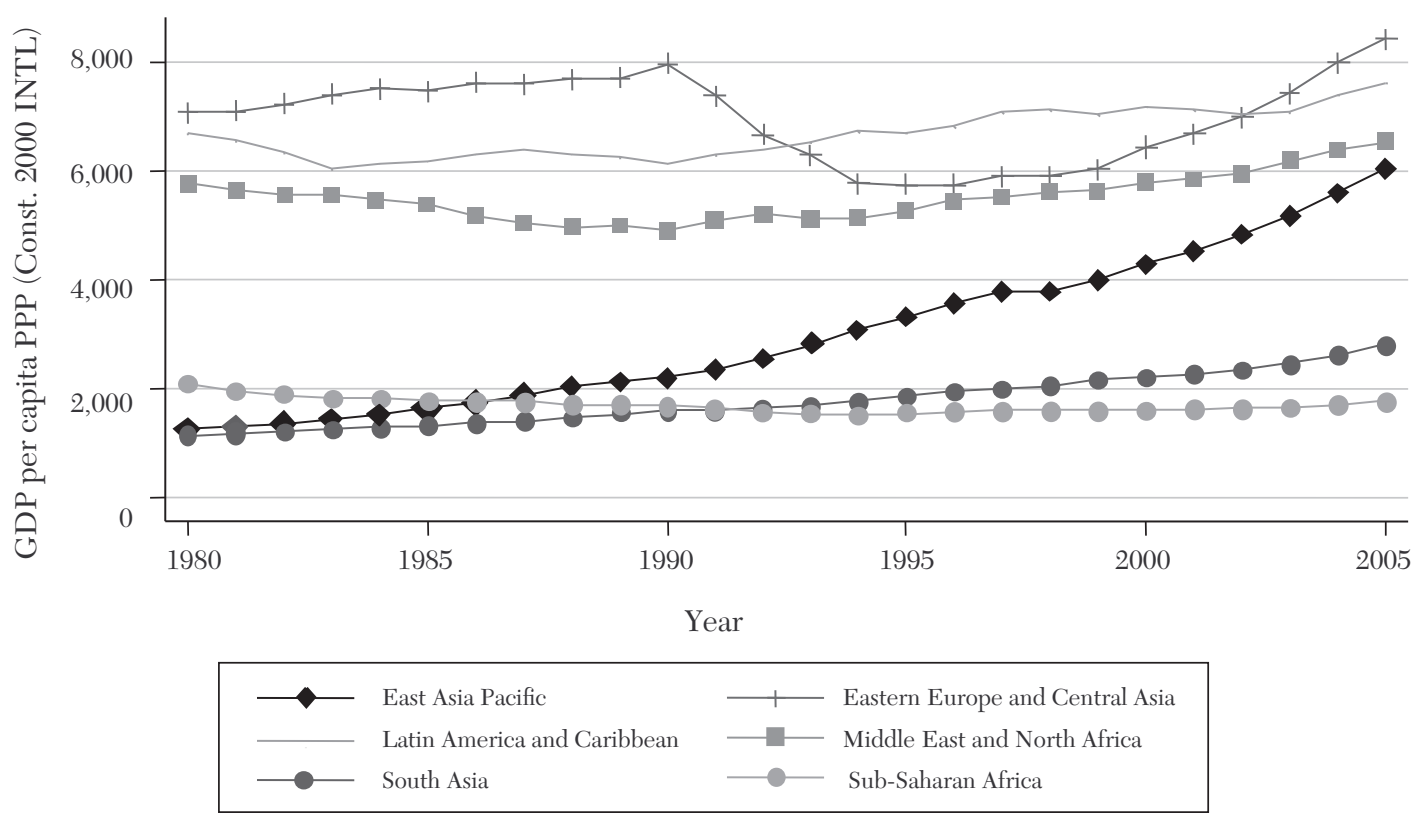

Figure 2. GDP Per Capita PPP (Const. 2000 INTL)

(Population Weighted Means by Continent)

Source: World Bank 2006b.

exceptions of China and the Middle East, the world has made significant strides in democratization. Latin America and Eastern Europe are the shining examples.

The World Bank presents figures on poverty based on Yuri Dikhanov (2005). Between 1980 and 2000, the share of the world's population living on less than $\$ 1$ a day fell from 34.8 percent to 19 percent. The World Bank forecasts that the number of people living on less than $\$ 1$ a day will continue to fall sharply despite population growth, and account for 10 percent of the world's population by 2015 . Ironically, the Millennium foreign aid project argues that massive increases in foreign aid are needed to reach this goal-the World Bank forecast suggests that such increases are unnecessary to reach the 10 percent goal. Billions of people in Asia have been lifted out of poverty thanks to economic growth; Sub-Saharan Africa, with little or no economic growth, is where the really poor are concentrated.

What about economic policies? Figure 7 shows that the world median (taken over countries) inflation rate in 1980 was 14.3 percent; by 2005 that median declined to 4.1 percent.

Figure 8 shows top marginal income tax rates, which fell around the world from the population-weighted average of 65 percent in 1980 all the way down to 36.7 percent in 2005.

Figure 9 presents official versus black market exchange rates, a common measure of financial liberalization. In the 1980s, most governments restricted foreign exchange transactions; by 2005 "black market" exchange rates have nearly vanished.

Figure 10 shows tariff rates, which fell from the population-weighted world average of 43 

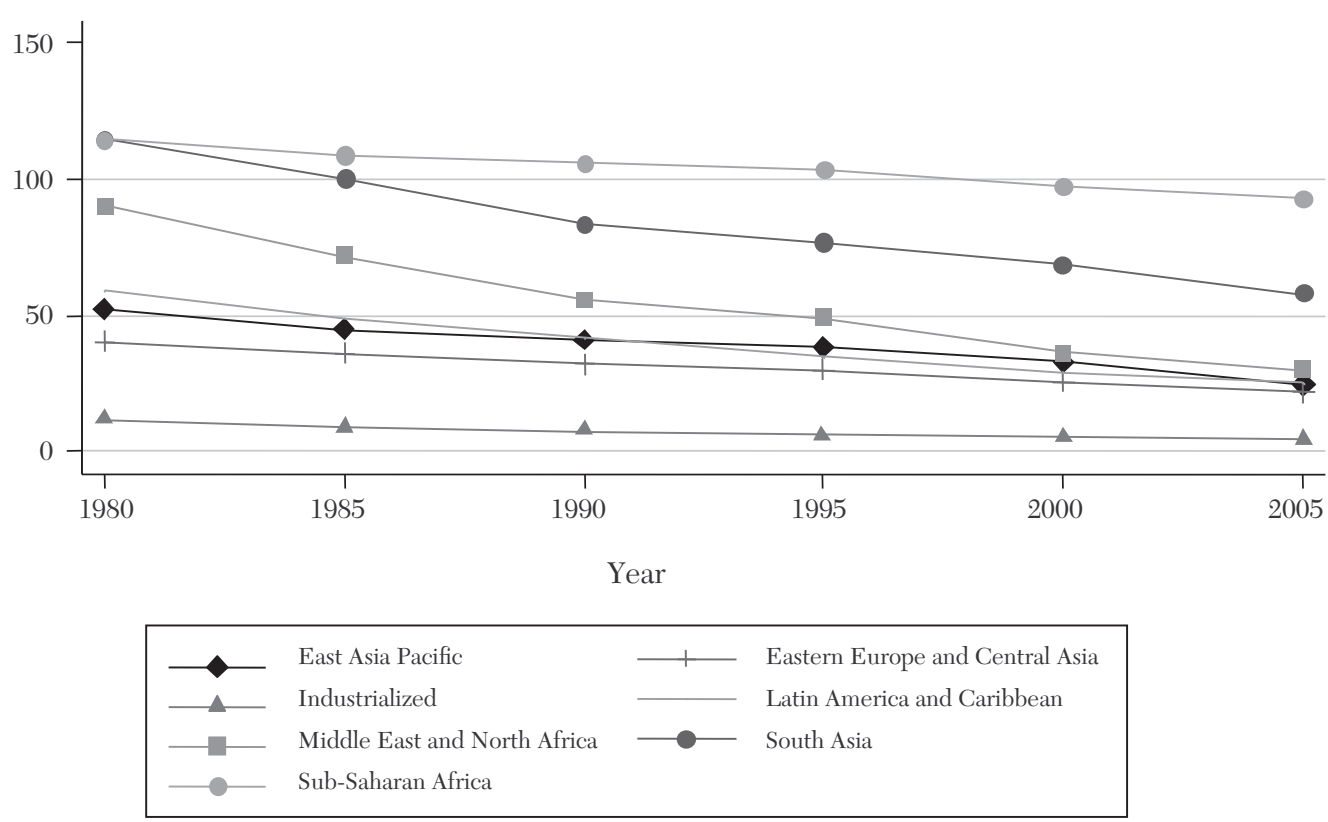

Figure 3. Mortality Rate of Infants (per 1,000 births) (Population Weighted Means by Continents)

Source: World Bank 2006b.

percent in 1980 to 13 percent in 2004, in parallel with vast expansion in world trade.

Finally, figure 11 presents much more recent data on trends in regulation, using the number of procedures an entrepreneur must follow before he can legally start a business (Simeon Djankov et al. 2002). These data are only available since 1999. Over the last six years, these data show downward trends, although East Asia and Latin America remain heavily overregulated.

The message of these figures is simple. In the Age of Milton Friedman, the world economy expanded greatly, the quality of life improved sharply for billions of people, and dire poverty was substantially scaled back. All this while the world embraced free market reforms. Is this a coincidence? Two recent books disagree on the answer.

\section{Balcerowicz-Fischer}

Balcerowicz and Fischer edited a collection of articles presented at a conference in Poland devoted to convergence among economies. Most of the contributions are country studies of economic reforms and their consequences. In addition to theoretical and historical papers, these include studies of China, Chile, Spain, Portugal, Greece, Ireland, as well as the Former Soviet Union. The conclusion of the book is summarized by the editors more than once: "reliance on market forces within an open economy in a stable macroeconomic environment, with assured property rights, are the keys to rapid economic growth." Milton Friedman would have put it better, but with the same idea. 


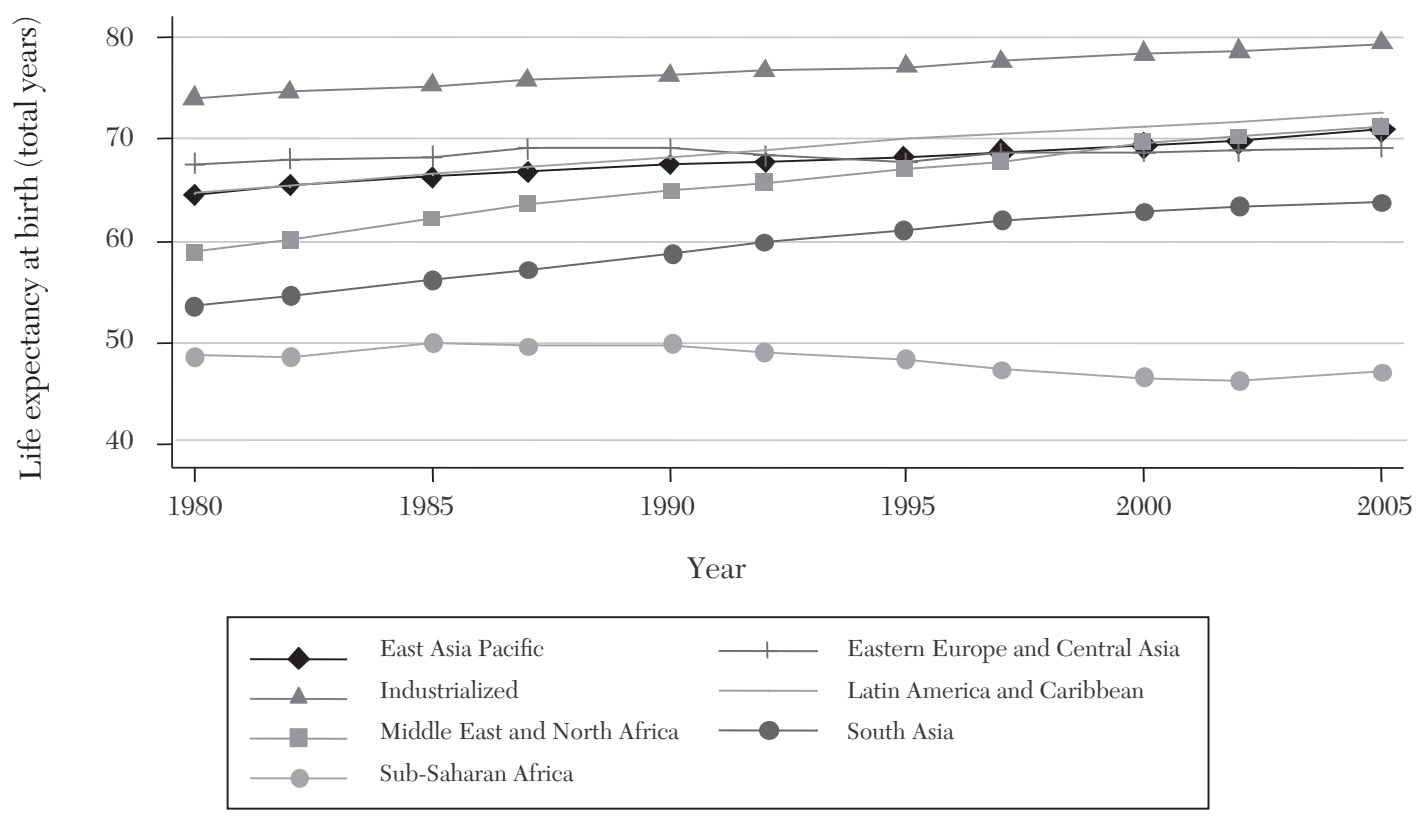

Figure 4. Life Expectancy at Birth (Total Years)

(Population Weighted Means by Continents)

Source: World Bank 2006b.

To convey the flavor of the book, I briefly focus on a few studies I liked the most. Wing Thye Woo asks whether the extraordinary success of China is due to its embrace of free market policies, or the deviations from those. Since the beginning of China's reforms, China specialists have argued that China succeeded in its transition because of its deviations from free market policies. First, there was the idea that China's township village enterprises, with their uncertain ownership structures, were responsible for its success. Others claimed that China's dual pricing system-in contrast to market pricing - avoided the bankruptcy of state enterprises, and thus helped economic growth. Still later, we heard that China's delay of privatization and retention of a large state sector explains its success. Woo debunks the argument that the key to China's success is anything other than its adoption of free market policies, and in particular of exportled growth. He presents a great deal of evidence, and his story is compelling. China, like much of the rest of Asia, succeeded because it embraced capitalism-including a largely open economy, financial stability, and reasonably secure property rights for entrepreneurs, despite, not because of, the "Chinese characteristics" of its program.

Anders Åslund draws attention to the extraordinary acceleration of growth in the former Soviet Union at the beginning of the twenty-first century. The growth has been pervasive, in both resource-rich and resource-poor countries, and has accelerated just as Eastern Europe began to slow down. Asslund was among the first to point out the explosion of growth in the region and to argue that market reforms have worked. Åslund's explanation of the acceleration of growth in 

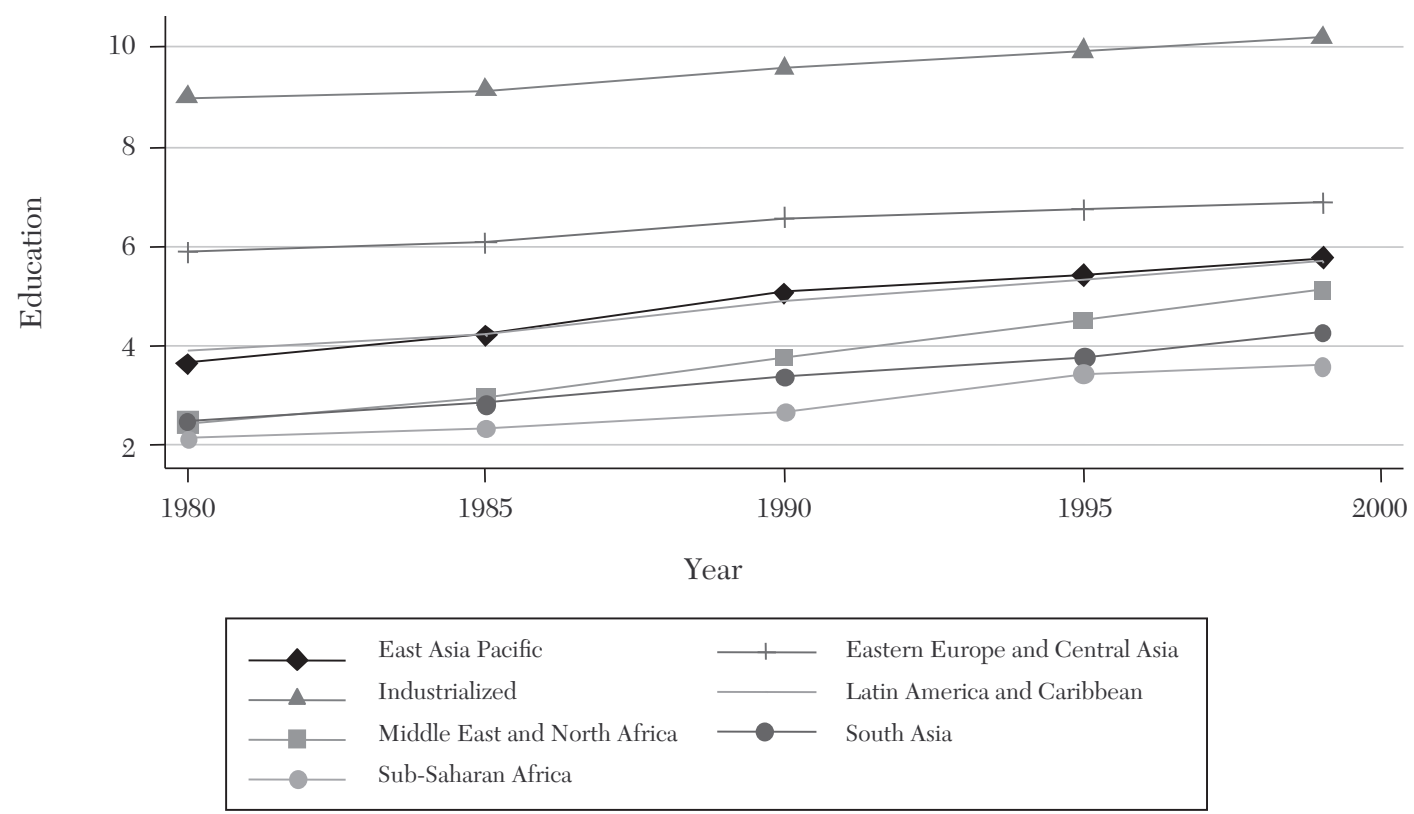

Figure 5. Education (Years of Schooling)

(Population Weighted Means by Continent)

Source: Barro and Lee 2000.

the former Soviet Union, and deceleration in Eastern Europe, is smaller government budgets and lower taxes in the former. There is much to be said for the huge success of low tax policies in many countries in the region during this period. But an important part of explaining the evidence is also the longer recession in the former Soviet Union: the fruits of free market reforms ripened in the late 1990s, five years after they did in Eastern Europe.

The collection also includes a pair of essays —one by Thomas O'Connell and Diarmaid Smyth and one by John Bradley-on Ireland, the miracle of Western Europe. As much as any other country in the world, Ireland embraced the prescriptions of Milton Friedman: trade openness, low taxes, low regulations, and balanced budgets. "The main lesson from the Irish experience is that there are certain key prerequisites necessary to sustain high growth-namely, sound macroeconomic policies, a strong commitment to free trade, a lightly regulated competitive microeconomic environment, and a well-educated and flexible labor force" (p. 285). Starting as one of Western Europe's laggards, Ireland became the richest country of the region in the span of one generation.

Nearly all the essays in the volume note roles of fiscal restraint and low inflation in encouraging economic growth. This is true about essays on wealthy economies joining the European Union, such as Spain, and those on developing countries, such as Chile. The Chile essay, by Vittorio Corbo L. and Leonardo Hernández T., includes a convincing discussion of the role of responsible fiscal policy and financial regulation in allowing the 

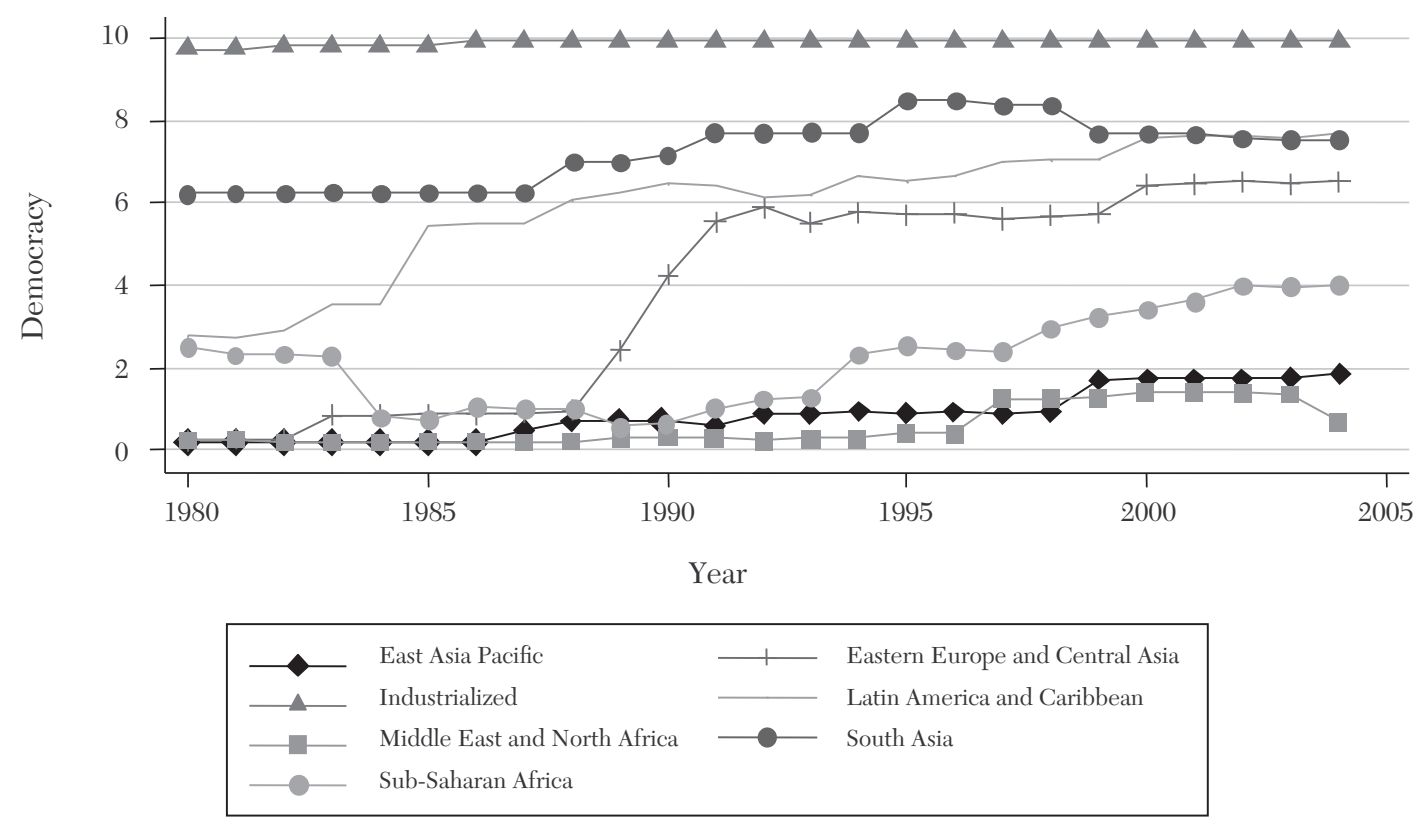

Figure 6. Democracy

(Population Weighted Means by Continent. $0=$ low $10=$ high)

Source: Jaggers and Marshall 2000.

country to sail smoothly through the Asian financial crisis. Corbo and Hernández briefly mention capital controls in Chile (a subject I later return to), but do not give them much credit for Chile's stability, and approvingly report their abolition in 2001.

Interestingly, the Balcerowicz-Fischer book is framed in terms of not just growth, but convergence. There is no talk of permanent backwardness, or of fundamental irreversible differences between, say, transition economies and the rich West European countries. Rather, the question is what policies will accelerate convergence. Nor is this thinking confined to transition economies. When I visited Chile a decade ago, its ambition was to overtake Argentina. When I visited in 2007, the question on the minds of many policymakers was convergence to
Australia and New Zealand. Such talk might be ambitious, but it shows where free market policies got the Chileans.

\section{Stiglitz et al.}

The world is a much gloomier place in the volume Stability with Growth by Stiglitz, Ocampo, Spiegel, Ffrench-Davis, and Nayyar (hereafter Stiglitz et al.). The book is an extended critique of free-market policies and their advocates, and a proposal for alternative policies. This volume does not deal with all the policies Stiglitz has embraced, such as state ownership and extensive regulation. It merely emphasizes the virtues of inflation and capital controls.

Central to the organization of the book, Stiglitz et al. classify economists concerned 

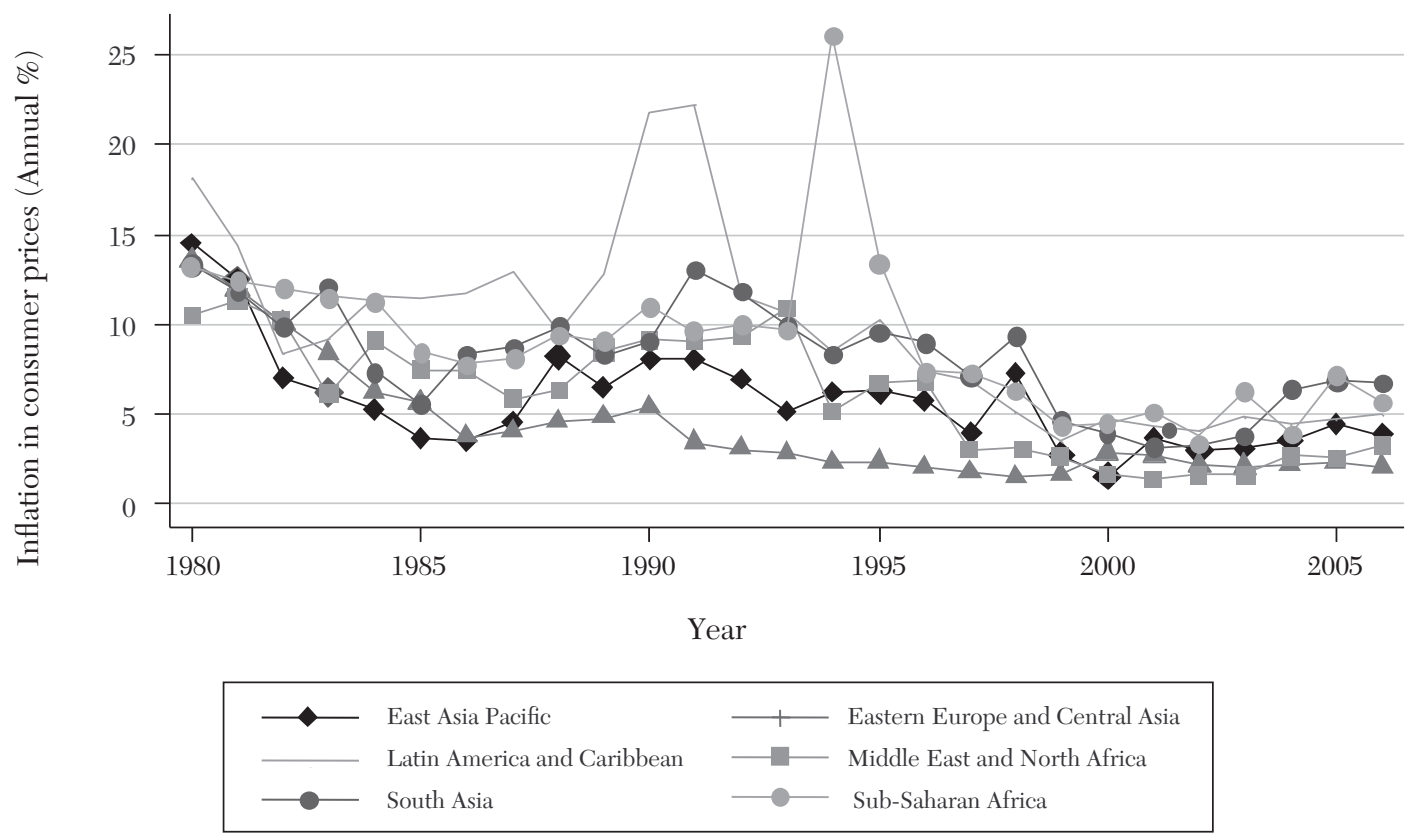

Figure 7. Inflation in Consumer Prices (Annual \%) (Median by Region. Excluding Eastern Europe and Central Asia)

Source: World Bank 2006b.

with policy into three types. The first is "standard Keynesian" economists, who adopt the 1960s Keynesian model and focus on countercyclical fiscal policy. Since most of these economists are long retired or dead by now, they receive little attention.

The second type is "conservative" or "neoclassical" economists (this is an upgrade from being called "market fundamentalists" in earlier Stiglitz books). Conservative economists, according to Stiglitz et al., rely on a neoclassical model that assumes competitive markets, rational consumers, and profit-maximizing firms. They do not believe in market failure and therefore in government intervention. They seek to achieve zero inflation and balanced budgets. Unfortunately for the world, in the 1990s these economists took over policy making at the IMF, the
World Bank, and the United States Treasury. As a consequence, the world came close to an economic cataclysm.

Finally, there are the "heterodox" economists, like Stiglitz et al. "The heterodox approach attempts to bridge the gap by building a coherent model of the economy, based on realistic micro-foundations, which recognize that information and markets are imperfect" (p. 39). In this approach, neoclassical factors play a bigger role than they do in Keynesian models, yet market imperfections are also appreciated. In other words, heterodox economists are reasonable middle-roaders squeezed between the two extremes of standard Keynesians and conservatives. Note the crucial rhetorical structure of the classification: just as consumers faced with the choice of three toasters-an expensive one, 


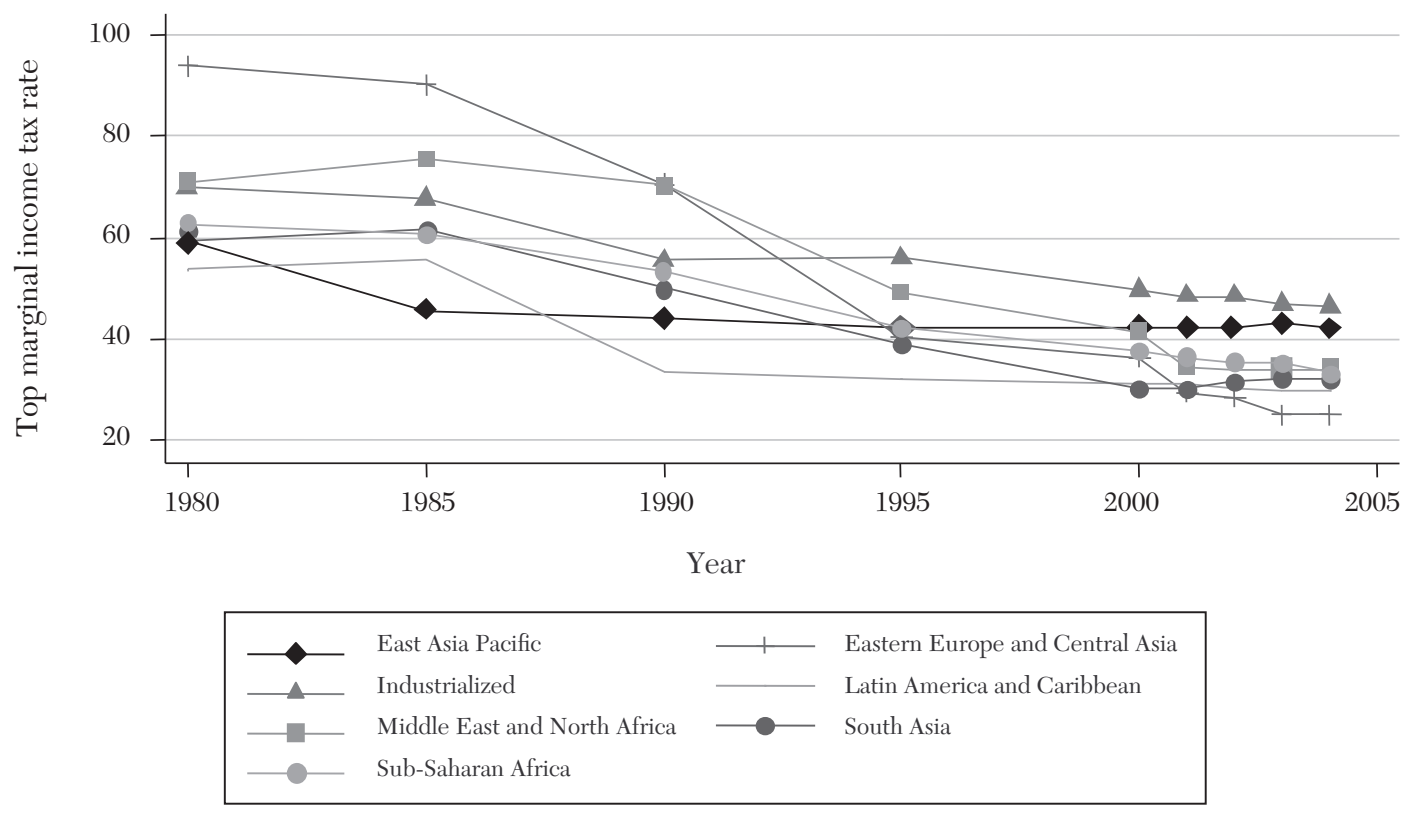

Figure 8. Top Marginal Income Tax Rate

(Population Weighted Means by Continents. Scale 0 to 100\%)

Source: Gwartney, Lawson, and Easterly 2006.

a cheap one, and a mid-price one-tend to pick the one in the middle, so a reasonable reader should avoid the extremes and opt for the "heterodox" position on economic policy. The image of Stiglitz as the man in the middle might surprise those who see him as the academic spokesman of the antiglobalizers, but here it is.

The deeper problem with the classification is that there are not many conservatives, as defined by Stiglitz et al., involved in economic policy making. Economists who have held high positions at the World Bank, the IMF, and the U.S. Treasury during the period in question can scarcely be described as Walrasian purists, let alone as conservatives. As Stiglitz et al. classify their targets, the traditional Keynesians are dead, and the conservatives are absent from the centers of economic policy making-abroad as well as in Washington, D.C. The book becomes a lopsided dialogue between the real (and heterodox) Socrates, and the fictitious (and conservative) Eutyphro.

Setting aside the rhetorical methods, consider the two substantive issues that Stiglitz et al. address. The first is inflation. Stiglitz et al. argue repeatedly that conservative economists believe in balanced budgets and zero inflation, but that in reality there is not much evidence that moderate inflation is detrimental to economic growth. To bolster this claim, Stiglitz et al. present one of the few tables in the book, aptly entitled "Countries where inflation has not impeded growth." The data for that table draw on a 1998 paper by Michael Bruno and William Easterly_Bruno presumably being one of 

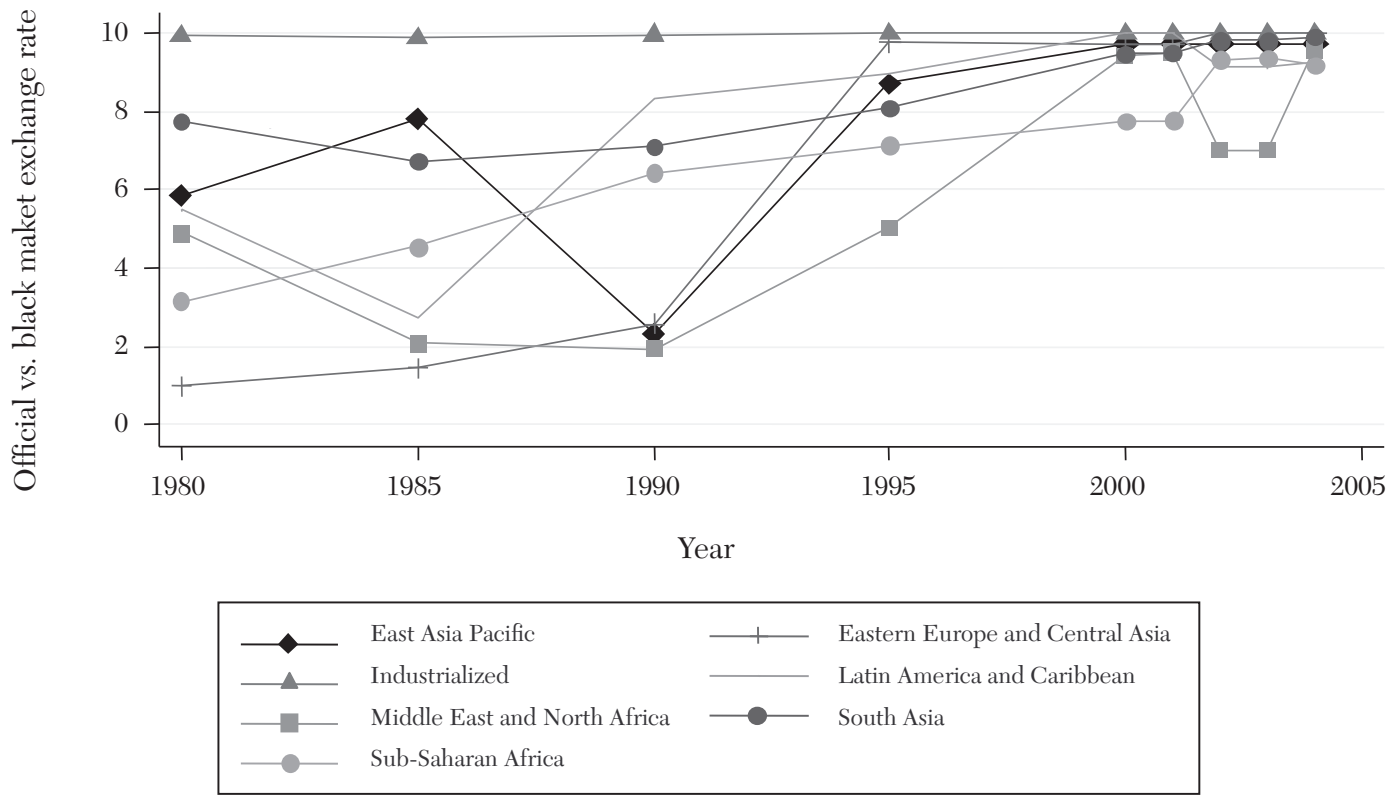

Figure 9. Official vs. Black Market Exchange Rate

(Population Weighted Means by Continents. Scale $0=$ worst to $10=$ best $)$

Source: Gwartney, Lawson, and Easterly 2006.

the "conservatives" who served as the Chief Economist of the World Bank in the 1990s. Bruno and Easterly find no evidence that inflation rates below 40 percent have adverse effects on growth. A more recent study (Mohsin S. Khan and Abdelhak S. Senhadji 2001) from the IMF presents evidence that the thresholds beyond which inflation has adverse effects on growth are lower, at 11 to 12 percent, not zero.

The point is not that there are literally no advocates of zero inflation for developing countries. I am sure there are some, although I did not find them, for example, in the Balcerowicz-Fischer volume. Rather, Stiglitz et al. claim for themselves the views that seem rather conventional in the corridors of power. And they express little concern for the huge costs that high inflation has brought to countries that lost control of their fiscal policy, including many Latin American and transition economies.

The second policy that Stigltz et al. attack is capital market liberalization. Instead, they favor capital controls as a way to stem the inflow and the outflow of speculative finance. In this, Stiglitz et al. clearly do not share the views of the authors of papers in Balcerowicz-Fischer, who generally see the integration into world capital (and not just goods) markets as an essential part of their nations' growth strategies.

Although the book presents little evidence, it repeatedly mentions the example of Malaysia as a country that imposed capital controls during the Asian crisis and that has recovered splendidly as a consequence. The question of whether capital 


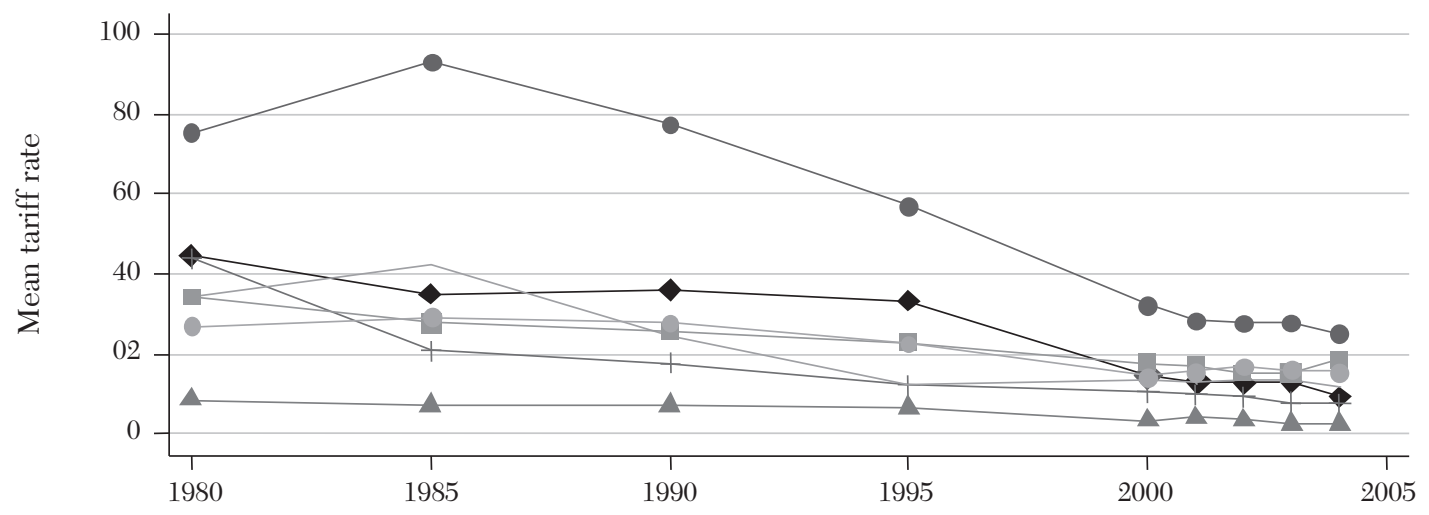

Year

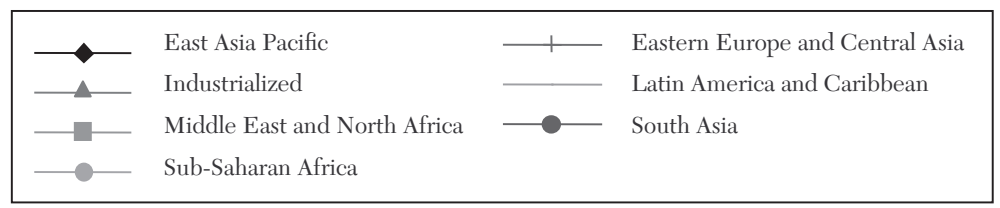

Figure 10. Mean Tariff Rate

(Population Weighted Means by Continents. \% Terms)

Source: Gwartney, Lawson, and Easterly 2006.

controls, which were imposed very late in the crisis, have helped Malaysia, is actually quite controversial, and many recent commentators fail to find evidence that they had macroeconomic benefits (see, e.g., Simon Johnson et al. 2006; Eswar S. Prasad and Raghuram G. Rajan 2008). Ironically, Stiglitz et al.'s own data show South Korea recovering much faster than Malaysia (p. 183), a finding they do not mention. In contrast, it is uncontroversial that capital controls in Malaysia have encouraged misallocation of capital and corruption-a key concern of the critics, which Stiglitz et al. briefly bring up and dismiss. Johnson et al. (2006) present compelling evidence that Malaysian capital controls encouraged corruption and benefited firms close to the Prime Minister.
One way to give the readers of this review an overall sense of this book is with an example. On p. 70, Stiglitz et al. chastise conservatives for objecting to fiscal deficits by making "arguments based on the hard-to-verify notion of confidence." "Despite how frequently conservatives invoke the confidence argument, there's remarkably little empirical research on the matter (including little research by the IMF which seems to rely on the confidence argument heavily)." Then, on p. 148, Stiglitz et al. attack George Bush's budget deficits, equally severely. "What will happen, not just to the United States, but to the stability of the global financial system if foreigners lose confidence (emphasis added) in the strength of the dollar, if they worry that it will depreciate in value in coming years?" A reader might lose confidence in the rest of the book. 

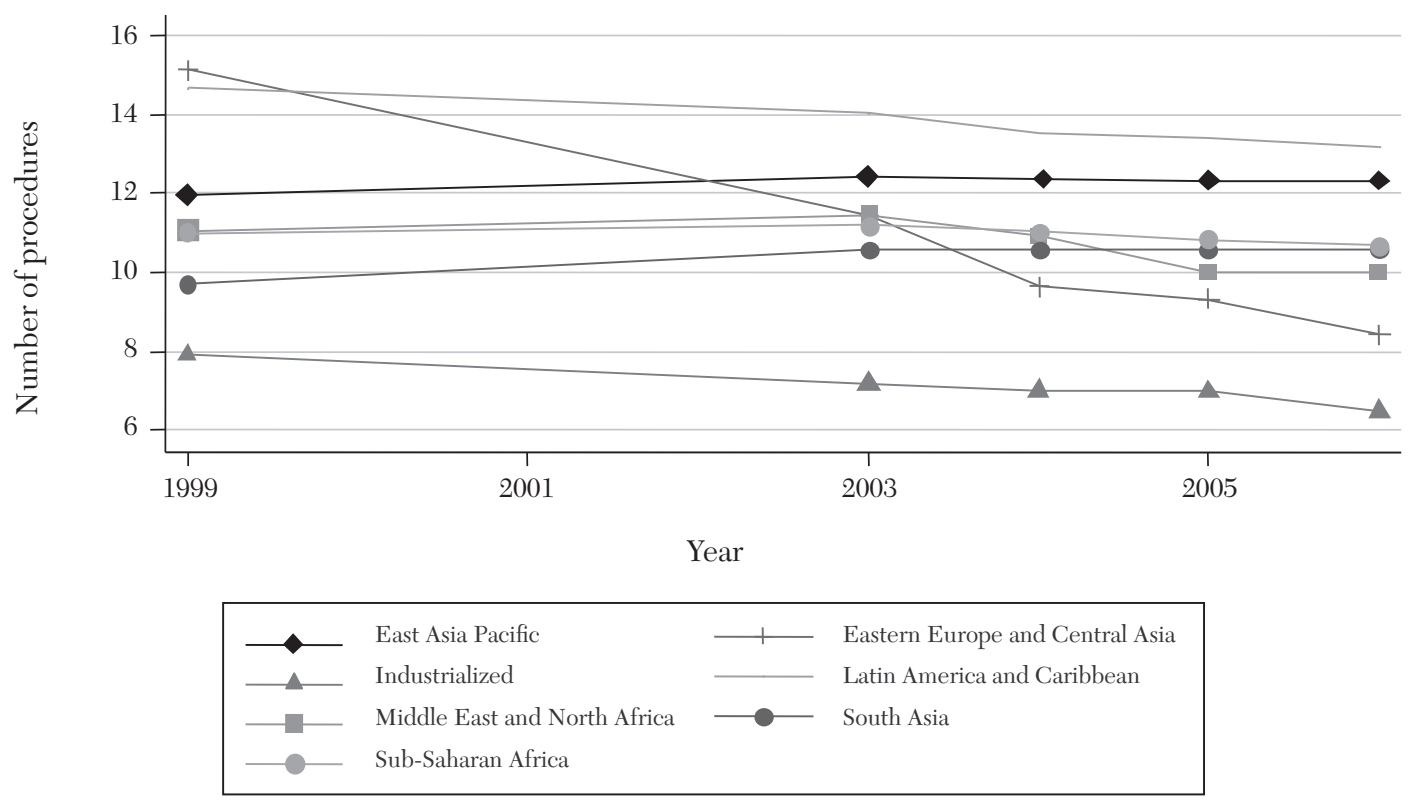

Figure 11. Number of Procedures to Start a Business (Population Weighted Means by Continents)

Source: World Bank 2006a.

\section{Conclusion}

The last quarter century of world development has presented economists interested in economic policy with many complex challenges. To name a few, economies moving from socialism to capitalism and embracing market policies at first collapsed, and began growing only after three to six years. The rapidly growing and heavily market oriented Asian economies suffered major setbacks in the late 1990s, with major recessions that slowed them down for at least a couple of years. The economies of South America embraced budget discipline and privatization in the 1980s and 1990s, yet showed truly lackluster economic growth. Importantly, many of these regions ended the era in a spurt of rapid economic growth, but the troubles along the way raised questions about appropriate tactics of policy reform.

Grappling with these questions improved our understanding of the workings of market economies, and of interactions between the state and the private sector. Transition has taught us that economic and political disorganization, combined with obsolete human capital of both economic agents and politicians, can sharply slow down the economic turnaround. The Asian crisis has reinforced the centrality of the financial system in the workings of a market economy, and exposed the vulnerability of that system to financial bubbles and generally imprudent financial arrangements. The Latin American experience has laid bare the fact that private ownership and fiscal prudence yield only limited benefits in a regime of overbearing 
taxation and regulation. All these episodes taught important lessons for the tactics of economic policy making.

Perhaps the crux of these lessons is to focus on the right problem. The two areas of the world facing most dramatic economic challenges today are Africa and Latin America. When thinking about their growth performance, surely the most obvious problem is the lack of new businesses and investment, particularly in the formal sector. It seems highly unlikely that the central challenges have to do with whether inflation should be above or below 10 percent (so long as public deficits are under control), or whether there should be a 0 or 1 percent transaction tax on capital flows (so long as capital markets are broadly open). It seems obvious that the central challenges have to do with the shortages of human capital, and with predatory regulatory and tax policies conducted by African and Latin American states. Indeed, my feeling is that reducing the burdens of (particularly corporate) taxation and regulation, and replacing extremely inefficient regulations with more appropriate ones, are the central challenges facing many developing countries today. The World Bank has properly drawn attention to the necessary reforms through its Doing Business report, and we have seen significant steps toward progress, especially among transition economies.

But tactics is only part of a broader strategy. On strategy, economics got the right answer: free market policies, supported but not encumbered by the government, deliver growth and prosperity. And while a lot has been accomplished in the last quarter century, a lot remains to be done. Most countries have embraced responsible fiscal policies, but it is far from clear that such policies can survive the volatility in the world's economy. World trade has a long way to go to become truly open. Many developing countries, especially in South Asia, Latin America, and Sub-Saharan Africa, urgently need government much less hostile to business. Many countries desperately need improvements in their legal systems, including bankruptcy systems, to secure property rights. Indeed, many Sub-Saharan African countries are rethinking their development strategies, after several state-centered false starts. It is far from a foregone conclusion that their governments will make good choices. We have a long haul ahead of us.

\section{REFERENCES}

Balcerowicz, Leszek, and Stanley Fischer, eds. 2006. Living Standards and the Wealth of Nations: Successes and Failures in Real Convergence. Cambridge and London: MIT Press.

Barro, Robert J., and Jong-Wha Lee. 2000. "International Data on Educational Attainment Updates and Implications." National Bureau of Economic Research Working Paper 7911.

-Bruno, Michael, and William Easterly. 1998. "Inflation Crises and Long-Run Growth." Journal of Monetary Economics, 41(1): 3-26.

Dikhanov, Yuri. 2005. "Trends in Global Income Distribution, 1970-2000, and Scenarios for 2015.” In UNDP Human Development Report 2005. New York: United Nations Development Programme.

-Djankov, Simeon, Rafael La Porta, Florencio Lopezde-Silanes, and Andrei Shleifer. 2002. "The Regulation of Entry." Quarterly Journal of Economics, 117(1): 1-37.

Gwartney, James, Robert Lawson, with William Easterly. 2006. Economic Freedom of the World: 2006 Annual Report. Vancouver: Fraser Institute. www. freetheworld.com

Jaggers, Keith, and Monty G. Marshall. 2000. "Polity IV Project." Center for International Development and Conflict Management, University of Maryland. http://www.systemicpeace.org/polity/polity4.htm.

Johnson, Simon, Todd Mitton, Kalpana Kochhar, and Natalia T. Tamirisa. 2006. "Malaysian Capital Controls: Macroeconomics and Institutions." International Monetary Fund Working Paper 06/51.

Khan, Mohsin S., and Abdelhak S. Senhadji. 2001. "Threshold Effects in the Relationship between Inflation and Growth." IMF Staff Papers, 48(1): 1-21.

- Prasad, Eswar S., and Raghuram G. Rajan. 2008. "A Pragmatic Approach to Capital Account Liberalization." Journal of Economic Perspectives, 22(3): 149-72.

Stiglitz, Joseph E., Jose Antonio Ocampo, Shari Spiegel, Ricardo Ffrench-Davis, and Deepak Nayyar. 2006. Stability with Growth: Macroeconomics, Liberalization, and Development. Oxford and New York: Oxford University Press.

World Bank. 2006a. "Doing Business." www.doingbusiness.org.

World Bank. 2006b. "World Development Indicators Online." 